\title{
Perception and expectation. What do patients really want from the dental treatment?
}

\author{
Percepção e expectativa. O que os pacientes realmente querem do tratamento dental?
}

\author{
Adriana Cristina ZAVANELLI ${ }^{1}$ \\ Mariana Vilela SÔNEGO' \\ Ricardo Alexandre ZAVANELLI² \\ José Vitor Quinelli MAZARO' \\ Rosse Mary FALCÓN-ANTENUCCI ${ }^{1}$
}

\section{ABSTRACT}

\section{Objective}

The aim of this study was to investigate the subjective aspects related to the perception of dental appearance and expectations of patients who receive dental treatment in graduation clinics of the Araçatuba Dental School.

\section{Methods}

It was evaluated 362 patients of both gender aged over 18. The questionnaire included questions of demographic data, questions to assess facial and dental aesthetics, dental satisfaction and treatments considering patients notion to improve dental esthetics. The data collected was analyzed using descriptive statistics and the chi-square test.

\section{Results}

The factor teeth for facial analysis and factor positioning in the arch for smile analysis were considered the most important subjects regarding the esthetic according to the respondents. $67.5 \%$ of patients were dissatisfied with the appearance of their teeth, and dissatisfaction with the color was the most important factor (66.8\%). The treatment most desired was tooth whitening and $85.0 \%$ of patients said yes to it.

\section{Conclusion}

Respondents place great value on the teeth on the face appearance, and it can be seen that aesthetic treatments are highly valued in all age groups. There is a need for treatments to restore the function, but treatments to improve dental appearance were the most requested.

Indexing terms: Esthetics, dental. Patient satisfaction. Surveys and questionnaires.

\section{RESUMO}

\section{Objetivo}

Avaliar os aspectos subjetivos relacionados à percepção da aparência dental e expectativas de pacientes que recebem tratamento odontológico nas clínicas de graduação da Faculdade de Odontologia de Araçatuba.

\section{Métodos}

Foram avaliados 362 pacientes de ambos os sexos com idade superior a 18. O questionário incluiu perguntas sobre dados demográficos, perguntas para avaliar a estética facial e dentária, a satisfação dental e tratamentos considerando a noção dos pacientes de melhorar a estética dental. Os dados coletados foram analisados por meio de estatística descritiva e o teste do qui-quadrado.

\section{Resultados}

O fator dentes para análise facial e o fator posicionamento no arco para análise sorriso foram considerados os temas mais importantes a respeito da estética, de acordo com os entrevistados. 67,5\% dos pacientes estavam insatisfeitos com a aparência de seus dentes, a insatisfação com a cor foi o fator mais importante $(66,8 \%)$. O tratamento mais desejado foi o clareamento dental e $85,0 \%$ dos pacientes disse sim a ele.

\section{Conclusão}

Os pacientes dão grande valor aos dentes sobre a aparência rosto, e ele pode ser visto que os tratamentos estéticos são altamente valorizados em todos os grupos etários. Há uma necessidade de tratamentos para restabelecer a função, mas os tratamentos para melhorar a aparência dentária foram os mais solicitados.

Termos de indexação: Estética dentária. Satisfação do paciente. Inquéritos e questionários.

\footnotetext{
${ }^{1}$ Universidade Estadual Paulista "Júlio de Mesquita Filho", Faculdade de Odontologia, Departamento de Materiais Odontológicos e Prótese. Araçatuba, SP, Brasil.

2 Universidade Federal de Goiás, Faculdade de Odontologia, Departamento de Reabilitação Oral. Av. Esperança, s/n., Campus Samambaia, 74605020G, Goiânia, GO, Brasil. Correspondência para / Correspondence to: RM FALCÓN-ANTENUCCI. E-mail: <rosse_falcon@yahoo.com.br>.
} 


\section{INTRODUCTION}

Esthetics is a branch of philosophy that studies the nature of what is considered beautiful' 1 . That perception of beauty may also be influenced by cultural, ethnic, or racial concepts of beauty. When planning treatment for esthetic cases, smile design cannot be isolated from a comprehensive approach to patient care. Achieving a successful, healthy, and functional result requires an understanding of the interrelationship among all the supporting oral structures, including the muscles, bones, joints, gingival tissues, and occlusion ${ }^{2}$.

The face is the key feature in the determination of human physical attractiveness. A harmonious smile plays an important role in establishing a good relationship between physical and facial beauty, as the teeth are considered important components in the architecture of facial disposition ${ }^{3}$.

The Dental Aesthetics has become essential nowadays, since most people dream of having a perfect smile and bright teeth. This tendency caused a major demand in aesthetic dentistry originated by modern society's concern with beauty ${ }^{4}$.

In general, people desire for pearly white teeth. Thus, tooth color is one of the most important factors determining satisfaction with dental appearance. Selfsatisfaction with tooth color decreases with increasing severity of discoloration. White teeth have been correlated with high ratings of social competence, intellectual ability, psychological adjustment and relationship status ${ }^{5}$.

Esthetics has become an important aspect of dentistry. Until about the last two decades, clinicians considered esthetics to be far less important than function, structure and biology. Today, however, if a treatment plan does not include a clear view of its esthetic impact on the patient, the outcome could be disastrous ${ }^{6}$.

Therefore, the aim of this study was to investigate the subjective aspects related to the perception of dental appearance and expectations of patients who receive dental treatment in graduation clinics of the UNESP Universidade Estadual Paulista, Araçatuba Dental School, Brazil.

\section{METHODS}

This evaluation was performed by analysis of structured interviewer guided questionnaire (Table 1) used to collect the information. The questionnaire was adapted from the idealized study by Tin-Oo, Saddki and Hassan ${ }^{7}$ because it is easy to understand and free of invasive tests. This study was approved by the Research and Ethics Committee (Human) process number 00667/2011, UNESPUniv Estadual Paulista, Aracatuba, Brazil.

A structured, interviewer guided questionnaire (Table 1) was used for data collection. The questionnaire consisted of questions on socio-demographic items including sex, age, and level of education, as well as questions related to facial, dental and smile aesthetics. Patients were also asked about their satisfaction with their then-current general dental appearance, satisfaction with tooth color and size and perceived misalignment of teeth. In addition, patients were asked to select the aesthetic treatments they wished to undergo, including orthodontic treatment, tooth whitening, crowns, tooth restorations and partial or total dentures.

The study included 362 patients of both sexes and aged over 18. Patients who agreed to participate signed a consent form. The exclusion criterion was the patient's refusal to answer the questionnaire perception of dental appearance and expectation. The collected data were tabulated with Excel 2010 and presented by means of descriptive statistics (absolute and percentage distributions) with Epi Info 3.5.2. The association between variables was assessed by the Chi-square test. 
Table 1. Questionnaire.

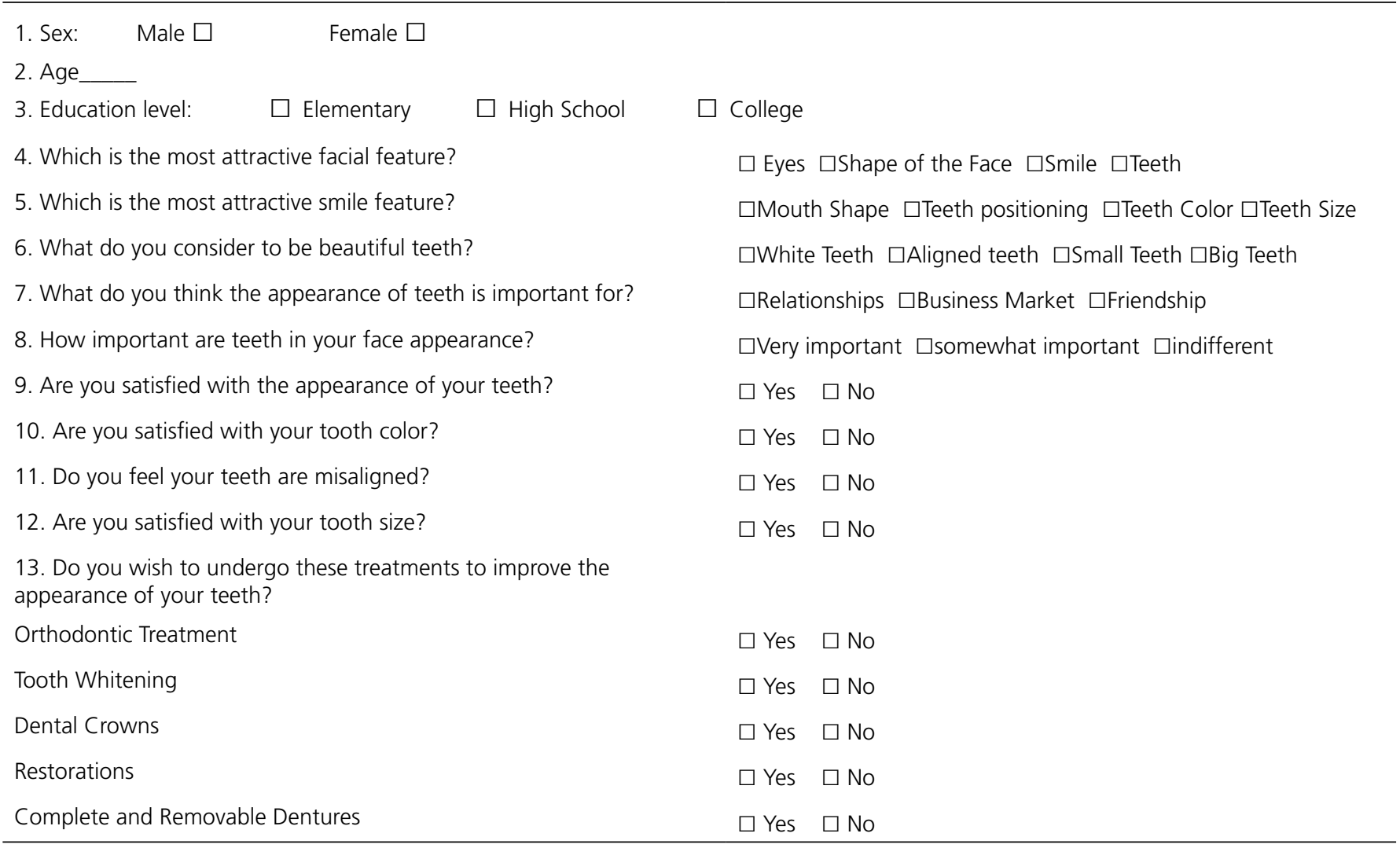

\section{RESULTS}

Out of 362 patients, 216 (59.7\%) were females and $146(40.3 \%)$ were males. The patients' age varied from 18 to 79 years, with a mean age of 43.3 years. To better assess the age distribution of respondents, they were divided into age groups. The educational level of the population was low, 123 (35.7\%) had attended primary school, 150 (43.5\%) had completed high school and 72 (20.9\%) had attended college.

As shown in Figure 1, teeth were considered the most attractive facial feature. There was a positive correlation (Table 2) with educational level ( $\mathrm{P}=0.0003)$. Patients with lower educational level considered the teeth as the most beautiful (primary school $56.7 \%$ and high school $49.0 \%$ ), whereas patients with higher education considered the smile as the most beautiful (50.0\%). Among what is considered to form a pleasant smile, $42.2 \%$ of patients considered teeth positioning as the most important feature (Figure 2).
Table 2. Associations between included variables.

\begin{tabular}{ll}
\hline Variables & P value \\
\hline Educational level/Facial feature & 0.0003 \\
Age/ Satisfaction with color & 0.0239 \\
Educational level/Tooth whitening & 0.0434 \\
Age/ Restorations & 0.0113 \\
Age/Complete and removable dentures & 0.0000 \\
Age/Crowns & 0.0000 \\
\hline
\end{tabular}

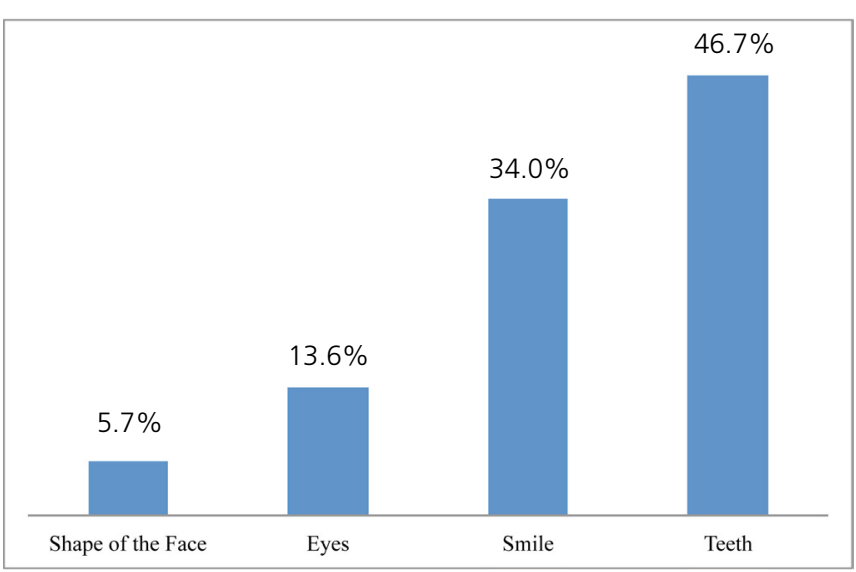

Figure 1. Patients' rating of facial feature. 


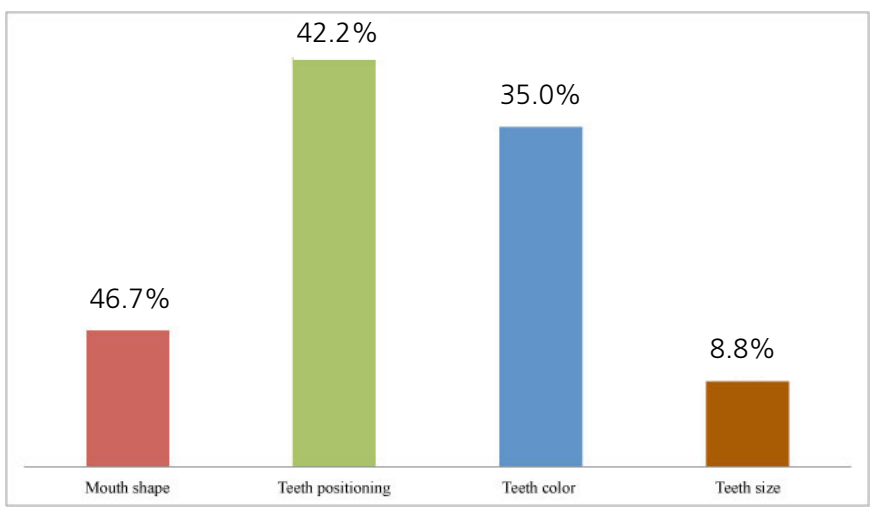

Figure 2. Patients' rating of smile feature.

When patients were asked what they considered to be beautiful teeth, $65.0 \%$ answered that it would be aligned teeth, $28.9 \%$ answered white teeth, $4.0 \%$ responded small teeth and $2.0 \%$ said that it'd be large teeth.

In the social importance of dental aesthetics, $47.8 \%$ think that appearance is important for relationships, $41.2 \%$ think the importance is business and $11.0 \%$ believe that dental aesthetics is important in friendship. Results showed that $94.2 \%$ of patients said that teeth were very important for face appearance, $3.1 \%$ said they were somewhat important and $2.8 \%$ said they were indifferent. Satisfaction with dental appearance was negative in most patients (Table 3), 67.5\% were dissatisfied with the appearance of their teeth. Positive correlation was found between age and color satisfaction ( $P=0.0239)$, patients aged older than 50 were more satisfied with teeth's color.

Table 3. Questions concerning patients' satisfaction

\begin{tabular}{|c|c|c|}
\hline \multirow{2}{*}{ Question } & \multicolumn{2}{|c|}{$\begin{array}{c}\text { Percentage of } \\
\text { subjects }(n=362)\end{array}$} \\
\hline & Yes & No \\
\hline $\begin{array}{l}\text { Are you satisfied with your tooth } \\
\text { appearance? }\end{array}$ & $32.5 \%$ & $67.5 \%$ \\
\hline Are you satisfied with your tooth color? & $33.2 \%$ & $66.8 \%$ \\
\hline Do you feel your teeth are misaligned? & $38.4 \%$ & $61.6 \%$ \\
\hline Are you satisfied with your tooth size? & $75.3 \%$ & $24.7 \%$ \\
\hline
\end{tabular}

Table 4. Questions concerning treatments patients desired to undergo.

\begin{tabular}{lcc}
\hline $\begin{array}{l}\text { Subjects' Desired Esthetic Dental } \\
\text { Treatments }\end{array}$ & \multicolumn{2}{c}{$\begin{array}{c}\text { Percentage of subjects } \\
(\mathrm{n}=362)\end{array}$} \\
\hline Orthodontic Treatment & $63.9 \%$ & No \\
\hline Tooth Whitening & $85.0 \%$ & $15.0 \%$ \\
Crowns & $66.7 \%$ & $33.3 \%$ \\
Restorations & $82.7 \%$ & $17.3 \%$ \\
Complete and Removable Dentures & $49.4 \%$ & $50.6 \%$ \\
\hline
\end{tabular}

According to Table 4, tooth whitening was the most desired treatment. Positive correlation was observed with the educational level of the patients and the desire to undergo the treatment $(\mathrm{P}=0.0434)$, more patients with a college degree said no to treatment (23.6\%).

Regarding restorations, significant correlation was found with age ( $P=0.0113)$, we observed lower acceptances with patients aged under 29 and over 60 . There was a statistically significant difference $(\mathrm{P}<0.05)$ when correlated to age of patients with the election of orthodontic treatment and also prostheses in general (Table 2). It was found a big lack of acceptance of patients younger than 29 years to complete and removable dentures, as the age of patients increased, also increased the acceptance to such treatment. Regarding crowns the acceptance was better, but the same pattern was found. In orthodontics, the ratio was reversed, the older patients had the lowest percentage of acceptance, but the greatest percentage was not found in the youngest patients.

\section{DISCUSSION}

Currently, the professional must abandon the traditional posture of seeing only the tooth or the specific request of the patient and observe more broadly the personality and expectations of his client. Aesthetic have become a very important factor ${ }^{4}$, in order to achieve the esthetic objectives the clinician must rely on a good treatment plan relying on several disciplines ${ }^{6}$.

Several studies state that patients (layperson) are able to perceive subtle changes regarding esthetic and deviation from normality almost as much as dentists, but their concept of facial attractiveness may be different ${ }^{8-10}$. Besides it is important to know that Laypeople generally are not aware of their facial profile, and photograph exposure previous to treatment can increase patients' profile self-awareness. Such procedure could reduce the discrepancy between dentists and patients' visual emphasis on dentofacial esthetics ${ }^{11}$.

This research aimed to evaluate the perception of dental and facial aesthetic factors of patients treated at the UNESP - Universidade Estadual Paulista, Araçatuba Dental School, as well as aesthetic perception of their dental condition and its current level of satisfaction. It also evaluated which treatments patients considered effective to improve the dental appearance. The sample consisted mostly of adult female patients with low educational level.

The questioning began with questions about the most attractive features of the face and smile. Teeth were 
found to be very important on facial esthetics some studies also reported teeth as the main facial feature, followed by the eyes ${ }^{3}$. Such result was confirmed when asked about the importance of teeth in the face appearance, subjects' response was almost unanimous, $94.2 \%$ said that teeth are very important.

The next part of the questionnaire assessed patients' satisfaction with their dental appearance. It was found that the majority of patients were dissatisfied with their dental appearance (67.5\%). It was a high percentage when compared to other studies. In the United Kingdom, only $24 \%$ of respondents were dissatisfied ${ }^{8}$. In Turkey ${ }^{12}$ the percentage of dissatisfaction was $55.1 \%$, in Israel ${ }^{6}$ was $37.7 \%$ and in Malaysia ${ }^{7}$ this percentage was $52.8 \%$. The factor with the highest percentage of dissatisfaction was the color of teeth $(66.8 \%)$, followed by lack of alignment.

Dissatisfaction towards color was found to be the most significant to appearance satisfaction ${ }^{8-13}$. Older patients ( $\geq 50$ ) were more likely to be satisfied with tooth color and patients ranging from 30 to 49 years had the highest percentage of dissatisfaction. The majority of studies report older to people to be more satisfied in an overall basis and to be more opened to treatments ${ }^{14}$. Age is not necessarily associated with poor self-perceived dental appearance, it is possible that older people might be less influenced by the media, while there is a great the pressure on the younger people to look beautiful and healthy, since there is a strong link between appearance and social status expressed by better jobs and social acceptability ${ }^{5}$.

Women seem to have a tendency to be more concerned towards esthetic ${ }^{15}$ and sometimes more dissatisfied ${ }^{7-8}$. In similar studies in Turkey ${ }^{8}$ and Malaysia7, women were more dissatisfied with their dental appearance, but in a study in Israel, males showed the highest dissatisfaction, even though the research was conducted in a military clinic and the sample consisted mostly of men ${ }^{6}$. In this study it was not verified positive association with gender and satisfaction, both men and women were equally dissatisfied.

The aesthetic treatment with the greatest impact on patients' opinion was the tooth whitening, and $85 \%$

\section{REFERENCES}

1. Peck S, Peck L. Selected aspects of the art and science of facial esthetics. Semin Orthod. 1995 Jun;1(2):105-26. doi: 10.1016/ S1073-8746(95)80097-2

2. Davis NC. Smile design. Dent Clin North Am. 2007 Apr;51(2):299318. doi: 10.1016/j.cden.2006.12.006 of patients said yes to the treatment. In other studies bleaching was also the most desired by patients ${ }^{7-8}$. Bleaching may have the highest requirement, but the percentage found requiring other treatments was also high. Regarding restorations, we observed a lower demand on the groups aged under 29 and over 60, and the highest demand among patients aged 40 to 49 . One possible explanation for this is that younger patients have more access to information on oral hygiene, and hence the prevention of caries. In the older population that did not happen, therefore it generated a greater need for prosthetic rehabilitation.

It was found great lack of acceptance from patients younger than 29 years to complete and removable dentures only $9.7 \%$ of these patients wanted to undergo such treatment. As the age of patients increased, also increased their acceptance to such treatment. In the fixed prosthodontics the acceptance was higher, but the same age/acceptance pattern was found.

\section{CONCLUSION}

The majority of patients were dissatisfied with their dental appearance; the main dissatisfaction reason was the color and as a consequence, the bleaching was the most desired treatment. Respondents place great value on teeth regarding the appearance of the face, and it can be seen that the aesthetic treatments are highly valued in all age groups. There is some need for treatments to restore the function, but the treatments to improve dental aesthetic were patients' most required.

\section{Collaborators}

AC ZAVANELLI and RA ZAVANELLI participated in the elaboration, development of the research and writing the article. MV SÔNEGO and JVQ MAZARO was responsible for the experimental phase (data collection, sample selection, analysis of the results, review of the literature). RM FALCÓN-ANTENUCCI was responsible for writing the article.

3. Jørnung J, Fardal $\varnothing$. Perceptions of patients' smiles: a comparison of patients' and dentists' opinions. J Am Dent Assoc. 2007;138(12):1544-53. doi: 10.14219/jada.archive.2007.0103

4. Spear FM, Kokich VG, Mathews DP. Interdisciplinary management of anterior dental esthetics. J Am Dent Assoc. 2006 Feb;137(2):160-9. doi: 10.14219/jada.archive.2006.0140

5. Alkhatib MN, Holt R, Bedi R. Age and perception of dental 
appearance and tooth color. Gerodontology. 2005 Mar;22(1):326. doi: 10.1111/j.1741-2358.2004.00045.x

6. Samorodnitzky-Naveh GR, Geiger SB, Levin L. Patients' satisfaction with dental esthetics. J Am Dent Assoc. 2007 Jun;138(6):805-8. doi: 10.14219/jada.archive.2007.0269

7. Tin-Oo MM, Saddki N, Hassan N. Factors influencing patient satisfaction with dental appearance and treatments they desire to improve aesthetics. BMC Oral Health. 2011 Feb 23;11:6. doi: 10.1186/1472-6831-11-6.

8. Kokich VO, Kokich VG, Kiyak HA. Perceptions of dental professionals and laypersons to altered dental esthetics: asymmetric and symmetric situations. Am J Orthod Dentofacial Orthop. 2006 Aug;130(2):141-51. doi: 10.1016/j. ajodo.2006.04.017

9. Pinho S, Ciriaco C, Faber J, Lenza MA. Impact of dental asymmetries on the perception of smile esthetics. Am J Orthod Dentofacial Orthop. 2007 Dec;132(6):748-53. doi: 10.1016/j. ajodo.2006.01.039

10. Pithon MM, Santos $A M$, Couto FS, da Silva Coqueiro $R$, de Freitas LM, de Souza RA, et al. Perception of the esthetic impact of mandibular incisor extraction treatment on laypersons, dental professionals, and dental students. Angle Orthod. 2012 Jul;82(4):732-8. doi: 10.2319/081611-521.1

11. Bonetti GA, AlbertiA, Sartini C, Parenti SI. Patients' self-perception of dentofacial attractiveness before and after exposure to facial photographs. Angle Orthod. 2011 May;81(3):517-24. doi:

\section{$10.2319 / 101510-606.1$}

12. Akarslan ZZ, Sadik B, Erten H, Karabulut E. Dental esthetic satisfaction, received and desired dental treatments for improvement of esthetics. Indian J Dent Res. 2009 AprJun;20(2):195-200. doi: 10.4103/0970-9290.52902

13. Xiao J, Zhou XD, Zhu WC, Zhang B, Li JY, Xu X. The prevalence of tooth discolouration and the self-satisfaction with tooth colour in a Chinese urban population. J Oral Rehabil. 2007 May;34(5):351-60. doi: 10.1111/j.1365-2842.2007.01729.x

14. Singh BP, Pradhan KN, Tripathi A, Tua R, Tripathi S. Effect of sociodemographic variables on complete denture satisfaction. J Adv Prosthodont. 2012;4(1):43-51. doi: 10.4047/ jap.2012.4.1.43

15. Ericsson JS, Östberg AL, Wennström JL, Abrahamsson KH. Oral health-related perceptions, attitudes, and behavior in relation to oral hygiene conditions in an adolescent population. Eur J Oral Sci. 2012 Aug;120(4):335-41. doi: 10.1111/j.16000722.2012.00970.x 